\title{
Price Levels, Exchange Rates, Interest Rates and Return on Equity of Commercial Banks in Nigeria
}

\author{
Malgit Amos Akims $^{1 *} \quad$ Job Omagwa $^{2} \quad$ John Mungai $^{2}$ \\ 1.Accounting and Finance Department, School of Business, Kenyatta University \\ 2. School of Business, Kenyatta University, P.O. Box 43844-00100, Nairobi, Kenya
}

\begin{abstract}
The fluctuation return on equity of commercial banks in Nigeria over the years has been a source of concern. This is largely due to the vital roles of commercial banks in the economic growth and development of the country. The study sought to assess the effect of price levels, exchange rates and interest rates on return on equity of commercial banks in Nigeria. The study applied annual panel data for the period 2010 to 2017. Correlation analysis indicates that price levels, exchange rates and interest rates had significant correlation with return on equity of commercial banks in Nigeria. Based on the panel regression analysis, the study found that price levels had insignificant effect on return on equity $(\beta=0.0027, p=0.0660)$. The study findings indicate that exchange rates had insignificant effect on return on equity $(\beta=-0.0002, p=0.0560)$. Interest rates had a significant effect on return on equity $(\beta=0.0139$, $\mathrm{p}=0.0110$ ) of commercial banks in Nigeria. The study therefore recommends that price discrimination can be employed by banks so as to apply different interest rates on loans to different customers which can be guided by their credit history. Additionally, the Central Bank should put in place effective monitoring mechanism in line with floors and ceiling for lending rates so as to protect customers from exploitation by commercial banks. Further studies can be done on the effect of price levels and exchange rates on return on equity of commercial banks in Nigeria due to the unique results obtained in this study.
\end{abstract}

Keywords: Price levels, Exchange Rates, Interest Rates, Return on Equity and Commercial Banks

DOI: $10.7176 /$ RJFA/11-10-10

Publication date:May $31^{\text {st }} 2020$

\subsection{Introduction and Background}

Commercial banks are vital for the smooth running and functioning of financial systems. Banks serve as repositories and custodians of very important financial information. Therefore, banks have the potentials to eliminate the information asymmetry related problems in the financial sector. The profitability of commercial banks further enhances the growth of economies through financial inclusion (making funds available for borrowing to investors) and financial deepening (Tariq, Usman, Mir, Aman \& Ali, 2014). This is due to the financial system not only serving as a platform for carrying out international transactions but also as a medium for foreign exchange traders (buyers and sellers) to interact and agree at an acceptable price for purposes of enhancing foreign transactions (Babazadeh \& Farrokhnejad, 2012). The economic growth and development of countries is therefore largely dependent on the banking sector (Bilal, Saeed, Gull \& Akram, 2013).

The return on equity of commercial banks in Nigeria has been characterized by a fluctuating trend (Central Bank of Nigeria, 2016). There was an increase in the return on equity of the industry from the $21.23 \%$ position to $23.14 \%$ as at December 2014 and June 2015 respectively. The positive change was attributed largely to large banks. The return on equity for large banks grew from $21.12 \%$ to $48.52 \%$ (by $27.4 \%$ points), while that of small and medium banks decreased by $10.1 \%$ and $6.6 \%$ points from $16.22 \%$ and $25.18 \%$ to $6.12 \%$ and $18.58 \%$ respectively. The return on equity for commercial banks in Nigeria was reported at $10.14 \%, 10.70 \%$ and $16.59 \%$ for the years 2015, 2016 and 2017 respectively (World Bank, 2020).

The operating environment of banks is characterized by external factors such as price levels, exchange rates and interest rates which exert influence on profitability of banks as they are not determined by bank management (Kimani \& Koori, 2018). Price levels impact on profitability as its fluctuation in an economy lead to changes in the revenue earnings of banks (Aremu, Ekpo \& Mustapha, 2013). Price levels bring about disruption in the business planning of banks. International banking would not be achieved without foreign exchange, because it is the financial part of transactions that are carried out through the payment and settlement systems of banks (Osundina, Ademola, Jayeoba \& Olayinka, 2016). Thus, the link between exchange rates and return on equity of banks

Exchange rate fluctuation translates into uncertainty of profits on foreign currency denominated contracts which result in a decrease in foreign trade to levels below what would have been without high fluctuation in exchange rates (Williams, 2018). Banks unlike other institutions have large responses to interest rate fluctuation. This is because banking operations are largely hinged on interest rates. Interest rates therefore, impact on the effective and efficient handling of bank portfolios such as liabilities and assets (Bektas, 2014). Interest rates notably influence the decision of banks to venture into unexplored areas for purposes of creating opportunities of enhancing profitability. 


\subsection{Statement of the Problem}

Commercial banks in Nigeria are key and contribute significantly to the economic growth of the country (Akinkunmi, 2017). As financial intermediaries, commercial banks provide variety of services to individuals, corporations and as well as government entities with the ultimate aim of achieving profits (Flamini, McDonald \& Schumacher, 2009). However, the fluctuating trend in return on equity of commercial banks in Nigeria which is further accompanied by downsizing of workforce in order to cater for operating costs is raising high concerns among various stakeholders (Muraina, 2018; Akani, Nwanna \& Mbachu, 2016).

Sheefeni (2015) contends that a country where a few commercial banks dominate the financial system (a similar case in Nigeria), any collapse or failure in the banking industry carries a negative resultant effect on the economy. This is because any bankruptcy in this industry has a potential multiplier effect which can bring about bank runs, banking crises which ultimately may lead to financial crises and other economic inefficiencies. Despite the theoretical and empirical linkages of price levels, exchange rates, interest rates and return on equity of banks, there is lack of concrete evidence to document such relationship in Nigeria; this therefore forms a basis for the current study.

Contradictory findings have been documented on the relationship between exchange rates and return on equity. Akani et al. (2016) and Osundina et al. (2016) found a positive effect of exchange rates on return on equity while Osuagwu (2014), Baba and Nasieku (2016) found a negative effect of exchange rates on return on equity. The current study sought to assess the effect of price levels, exchange rates and interest rates on return on equity of commercial banks in Nigeria.

\subsection{General Objective}

The general objective of the study was to assess the effect of price levels, exchange rates and interest rates on return on equity of commercial banks in Nigeria.

\subsubsection{Specific Objectives}

The study was guided by the following specific objectives:

i) To establish the effect of price levels on return on equity of commercial banks in Nigeria.

ii) To determine the effect of exchange rates on return on equity of commercial banks in Nigeria.

iii) To examine the effect of interest rates on return on equity of commercial banks in Nigeria. Null hypotheses were tested in view of the above specific objectives of the study at 0.05 significance level

\subsection{Theoretical Review}

The study applied Agency Theory and Expectations Theory of Exchange Rates to support the relationship between the research variables.

\subsection{Agency Theory}

Agency Theory was brought forth by Jensen and Meckling in 1976. Daily, Dalton and Canella (2003) put forward that the prominence of Agency Theory is attributed to its simplicity which narrows the firm and its various activities into two major participants, which are shareholders and managers. Also, the notion of individuals as human beings having their own self interests and the pursuant of these interests before and/ or at the detriment of other individuals (owners). Agency Theory rests on the nexus that exists between the firm's management and the owners of the firm who are usually the shareholders (Rashid, 2013). The theory asserts that there exists agency conflict in such a relationship. The management of firms are regarded as the agents who are contracted by the shareholders, thereby, vested with the responsibility of running the firm and enhancing the value of shareholders through good performance and as well as shareholders' wealth maximization.

\subsection{Expectations Theory of Exchange Rates}

Expectations Theory was propounded by Roberts in 1980. Expectations Theory of Exchange Rates is hinged on the notion that individuals formulate various expectations regarding exchange rates based on market information about demand and supply and other economic factors. Exchange rates are determined by expectations and shortterm speculation of foreign exchange dealers (Ramli \& Jusoh, 2015). The theory defines such expectations as equal to the optimal forecast, that is, the best guess of the future which is based on all available market information (Estes \& Polnick, 2012). Expectations Theory of Exchange Rates is relevant to this study as it is based on the notion that different people formulate or have expectations regarding exchange rates based on all available market information. Key to this theory is how collective expectations of individuals affect demand and supply of currencies in a country, which by extension affects exchange rates of such country.

\subsection{Empirical Review}

Almaqtari, Al-Homaidi, Tabash and Farhan (2018) analyzed the factors affecting profitability of commercial banks in India. The study had a sample size of sixty nine (69) covering the time period 2008-2017. Return on equity and 
return on assets were employed as proxies for profitability. The model for return on equity indicated that exchange rate fluctuation does not significantly predict the profitability of commercial banks in India. Kohlscheen, Murcia and Contreras (2018) explored the various determining factors of profitability of banks in emerging markets. The distribution of the sample was based on seven (7) economies from Asia, five (5) each from central and Latin America, Eastern Europe and also South Africa and Israel were included. The time scope for the study was 2000 to 2014. The study further revealed that price level fluctuation had an insignificant positive effect on return on equity. The study further revealed that short-term and long-term interest rates had insignificant effect on return on equity of banks. Due to the varying regulatory frameworks and economic conditions of countries, the findings of these studies may not be directly applicable to the Nigerian context.

Akinkunmi (2017) studied the variables determining the profitability of banks in the Nigerian context. The study focused on the period 2001 to 2015 while using ordinary least square and GMM. The study reported that price levels had a positive and insignificant effect on return on equity of banks. However, the study was largely based on bank specific characteristics unlike the current study which focused on external factors. Akani et al. (2016) investigated the impact of selected factors on financial performance of banks in the Nigerian context. The study was based on the period 1980 to 2014 and data was analyzed using co-integration and VECM. Research findings indicated that exchange rates and interest rates had a positive and significant effect on return on equity.

Baba and Nasieku (2016) explored the effect of external variables on financial performance of commercial banks in Nigeria. The time scope of the study was the period 2006 to 2015 where panel regression analysis was applied. The study findings indicated that exchange rates and interest rates had negative and significant effect on return on equity of commercial banks. The findings indicate that price levels had a positive and significant effect on return on equity of commercial banks. Lagat and Nyandema (2016) studied the effect of exchange rate fluctuation on financial performance while focusing on commercial banks listed at the Nairobi Securities Exchange. Correlation research design was applied and the population comprised of the ten (10) listed banks for the period 2006 to 2013. The study documented that exchange rates had an insignificant positive effect on return on equity. The study further reported that interest rates had an insignificant negative effect on return on equity of commercial banks. The study however was on listed commercial banks in Kenya.

Antwi and Apau (2015) explored the factors determining the financial performance of Rural and Community Banks (RCBs) in Ghana. The study was based on purposive sampling where thirty (30) rural and community banks in Ghana were selected within the time frame 2006 to 2010. The study utilized regression analysis based on panel data. The study findings indicate that inflation had a positive and significant impact on financial performance of rural and community banks. Notably, the findings of the study are based on community banks in Ghana.

Majok (2015) studied the impact of exchange rates on performance of commercial banks situated in Kenya. Descriptive research design was utilized where data was analyzed using multiple regression analysis. Findings indicated that exchange rates had a negative but insignificant impact on performance of commercial banks. The varying market conditions of countries make the findings not directly applicable to the Nigerian context. Sheefeni (2015) assessed the determinants of banking sector profitability in the context of Namibia. The study found that price levels do not significantly influence the profitability of banks in Namibia. The research was based on banks in the context of Namibia where aggregated data based on a time series regression was used.

Osamwonyi and Chijuka (2014) evaluated the impact of external variables on the profitability of listed commercial banks operating in Nigeria. The study focused on periods between the years 1990 to 2013 with the use of pooled ordinary least method. The study findings indicated that price levels and interest rates had negative and insignificant impact on return on equity of banks in Nigeria. Osuagwu (2014) examined the determinants of bank profitability in Nigeria. The study utilized unbalanced panel data for the time scope ranging from 1980 to 2010 which was analyzed using panel regression analysis. Research findings indicated that exchange rates had a negative and insignificant effect on profitability in terms of return on equity. The current study focused on all commercial banks which fully operated in Nigeria for the period 2010 to 2017.

Kanwal and Nadeem (2013) assessed the impact of external factors on profitability of listed commercial banks in Pakistan. The study documented that real interest rates had a positive and significant impact on return on equity. Alper and Anbar (2011) investigated the micro and macro determinants of bank profitability in Turkey for the time scope ranging from the years 2002 to 2010 . The study found that real interest rate is a significant determinant as it impacts positively on profitability of banks. Results indicate that price levels had no significant effect on profitability. The study concluded that higher interest rates bring about higher profitability of banks. Notably, the former focused on listed commercial banks in Pakistan and the latter was exploratory as it centered on determinants of profitability of commercial banks in Turkey. The present study focused on commercial banks in Nigeria.

Gul, Irshad and Zaman (2011) examined the nexus between micro and macro characteristics and bank profitability in Pakistan. The top 15 commercial banks in Pakistan constituted the sample of the study. The analysis of data was based on pooled ordinary least squares (POLS) and the findings indicated that price levels had positive and significant nexus with profitability of banks. Khrawish (2011) assessed the determinants of bank performance in the context of Jordan. The study focused on commercial banks for the time period 2000 through 2010 where 
multiple regression model was utilized for the analysis of research data. Research findings from the analysis indicated that exchange rates have positive and significant relationship with return on equity. However, the former was based on Pakistan and the latter was focused on Jordanian banks. As such the findings may not be applicable to commercial banks in Nigeria due to the different economic conditions such as market size and concentration of countries.

\subsection{Methodology}

The study was based on positivism doctrine. The present study adopted causal research design. The choice of causal research design was based on the fact that it is quantitative, preplanned and also structured in nature. As put forward by Cooper and Schindler (2009), it entails an inquiry into the cause and effect relationships among research variables. The study was based on purposive sampling design where the focus was the seventeen commercial banks which fully operated in Nigeria for the period 2010 to 2017 . However, due to unavailability of data, only fifteen of these banks were covered.

\subsection{Empirical Model}

The study was based on panel regression technique where return on equity was expressed as a function of price levels, exchange rates and interest rates. The general model of the study was adopted from Al-Khouri (2012) as follows:

$\mathrm{Y}_{\mathrm{it}}=\beta_{0}+\beta \mathrm{X}_{\mathrm{t}}^{\prime}+\varepsilon$ 1

Where:

$\mathrm{Y}_{\text {it }}=$ Return on Equity

$\mathrm{i}=$ Commercial Bank

$\mathrm{t}=$ Time Period

$\mathrm{X}^{\prime}=$ Vector of independent variables at time $\mathrm{t}$ (price levels, exchange rates and interest rates)

$\beta=$ Coefficients

$\beta_{0}=$ Constant term

$\varepsilon=$ Error term

Equation 1 above was decomposed into equation 2 which was utilized for estimation.

$\mathrm{ROE}_{\mathrm{it}}=\beta_{0}+\beta_{1} \mathrm{PL}_{\mathrm{t}}+\beta_{2} \mathrm{ER}_{\mathrm{t}}+\beta_{3} \mathrm{IR}_{\mathrm{t}}+\varepsilon$

Where:

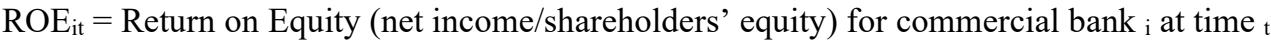

$\mathrm{PL}_{\mathrm{t}} \quad=$ Price Levels (inflation rate) at time ${ }_{\mathrm{t}}$

$\mathrm{ER}_{\mathrm{t}} \quad=$ Exchange Rates (Naira/United States Dollar exchange rates) at time $\mathrm{t}_{\mathrm{t}}$

$\mathrm{IR}_{\mathrm{t}}=$ Interest Rates (bank lending rates) at time $\mathrm{t}_{\mathrm{t}}$

$\beta_{1}, \beta_{2}, \beta_{3}=$ Coefficients

$\varepsilon=$ Error term

\subsection{Descriptive Analysis}

The descriptive analysis provides statistics which include the minimum and maximum values, mean and standard deviation of the study variables namely price levels, exchange rates, interest rates and return on equity (ROE) for the period 2010-2017. The descriptive statistics are presented in Table 1.

Table 1: Descriptive Statistics

\begin{tabular}{lllll}
\hline & PL & ER & IR & ROE \\
\hline Minimum & 8.00 & 150.30 & 16.01 & -0.040 \\
Mean & 11.71 & 220.72 & 16.67 & 0.008 \\
Maximum & 18.55 & 305.79 & 17.59 & 0.170 \\
Std. Deviation & 3.10 & 47.83 & 0.41 & 0.032 \\
\hline
\end{tabular}

Source: Study Data (2019)

Key: $\mathbf{P F}=$ Price Levels, $\mathbf{E R}=$ Exchange Rates, $\mathbf{I R}=$ Interest Rates and $\mathbf{R O E}=$ Return on Equity

The descriptive statistics in Table 1 indicated that the predictor variables had means above the standard deviations, thus reducing the likelihood of outliers or random errors in the data set. Price levels had minimum and maximum values of 8.00 and 18.55 respectively. A mean and standard deviation of 11.71 and 3.10 respectively were further reported for price level fluctuation. This therefore is an indication that price levels relatively fluctuated over the study period. Exchange rates had a minimum value of 150.30 and a maximum value of 305.79 . This is an indication that the study period was characterized by high exchange rate fluctuation which is further supported by a mean of 220.72 and a standard deviation of 47.83 .

Interest rates had minimum and maximum values of 16.01 and 17.59 respectively. Interest rates further had a mean of 16.67 and standard deviation of 0.41 . This therefore indicates that interest rates highly fluctuated within the period 2010 to 2017 . Return on equity had a mean lower than the standard deviation. This therefore indicates 
a wide range of variation in return on equity of commercial banks. This is also an indication that the data set was sourced from different units (that is, different banks).

\subsection{Trend Analysis}

This section presents trend analysis on the various research variables. The discussions for each of the variables are presented thereafter.

\subsubsection{Price Levels}

This section presents the trend of price levels as measured using inflation rate. The trend is presented in Figure 1.

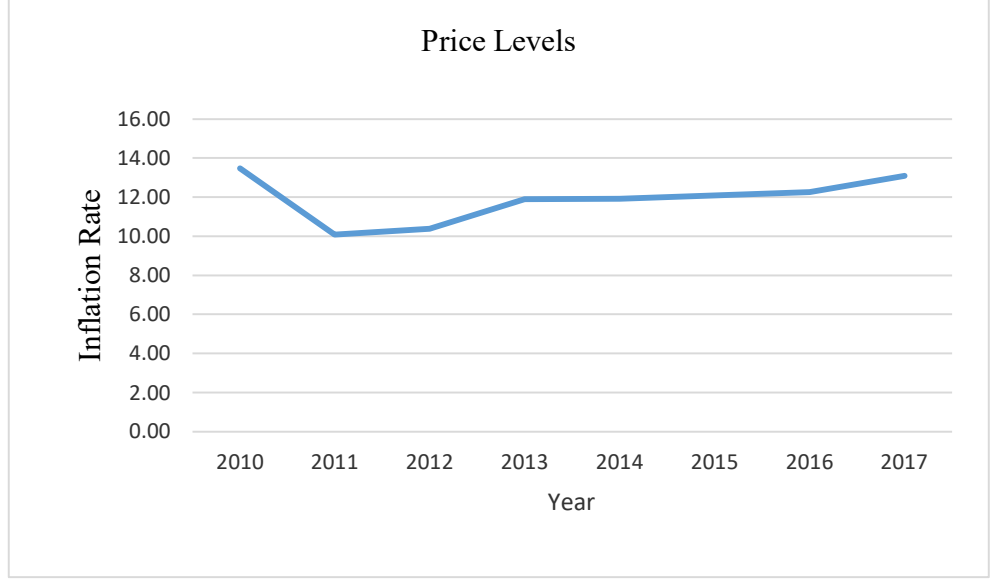

Figure 1: Trend in Price Levels

Source: Study Data (2019)

Figure 1 shows that, there was a partial fluctuation in price levels between the years 2010 to 2013 . The trend then stabilized between the years 2014 to 2016 but increased slightly in the year 2017. The increase in price levels in the period 2016 to 2017 can be associated with huge liquidity injections into the economy by the federal government (Akinkunmi, 2017).

\subsubsection{Exchange Rates}

This section presents the trend of exchange rates based on Naira/USD Exchange Rates. The trend is depicted in Figure 2.

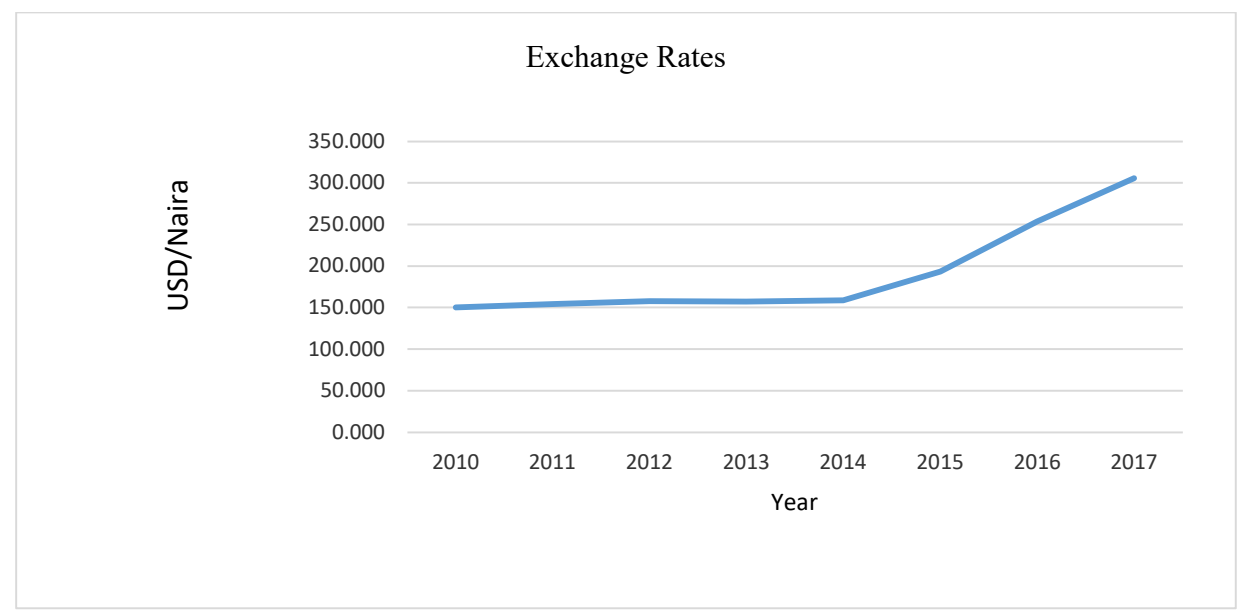

Figure 2: Trend in Exchange Rates

Source: Study Data (2019)

Figure 2 shows that, there was a stable trend in exchange rates from the year 2010 to 2014 . However, the years 2014 and 2015 saw the beginning of an increase in the trend of exchange rates. The rise is associated with the decline in international oil prices and ultimately revenues from crude oil which is largely the source of external reserves and in turn exchange rate stability in Nigeria (Akims, 2016).

Akinkunmi (2017) put forward that, the 2015 general elections in Nigeria brought about uncertainties that resulted to volatility in the financial system. This was further accompanied by excessive demand for foreign currencies in the foreign exchange market for election purposes. In 2016, the Central Bank of Nigeria scrapped the currency peg against the dollar which initially kept the naira at an artificially high value of 197 to 1 USD. The scrapping of the currency peg was a move geared towards addressing the high foreign currency shortages which 
hampered the growth of the Nigerian economy. This however, further depreciated the value of the naira as it resulted to a fall of over 40 percent in the value of the Naira against the US dollar. The rising exchange rate of Naira/USD was further witnessed in the year 2017.

\subsubsection{Interest Rates}

This section presents the trend of interest rates based on bank lending rates. The trend is shown in Figure 3.

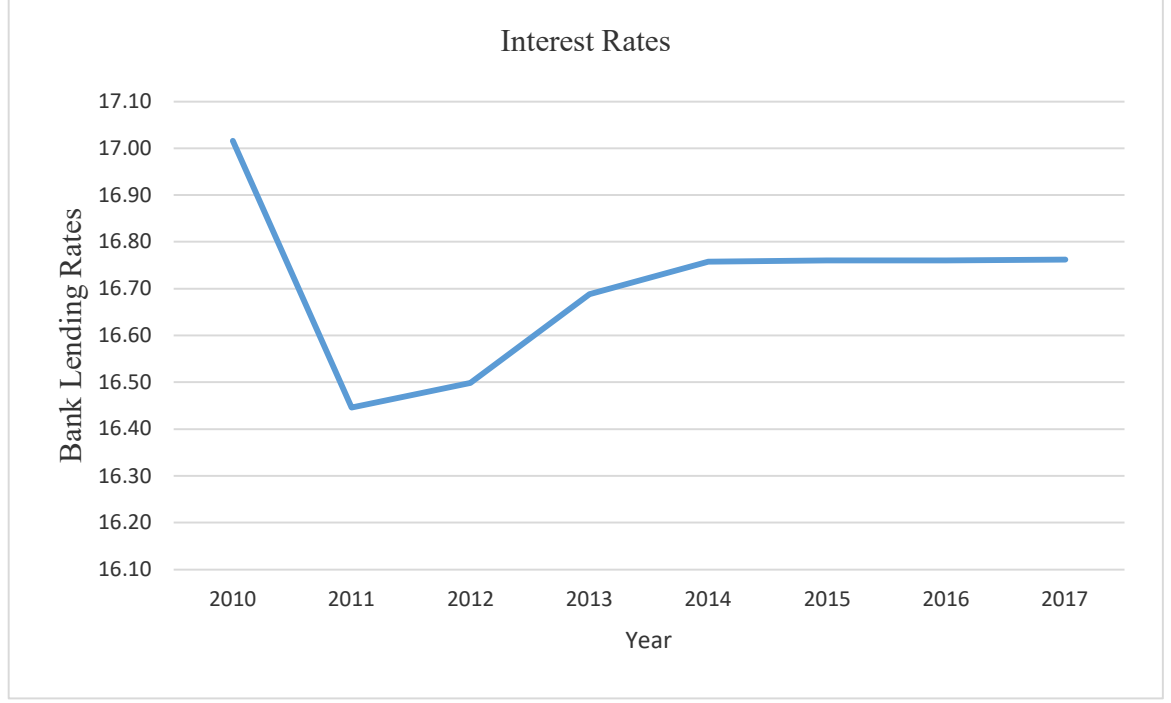

Figure 3: Trend in Interest Rates

Source: Study Data (2019)

Figure 3 indicates that, there was a sharp decrease in interest rates from the period 2010 to 2011 . This was followed by an increasing trend from the period 2011 to 2014 . However, from the period 2014 to 2017, interest rates remained stable. The prevailing interest rates in Nigeria are principally influenced by the actions of the monetary authority or central bank. Central banks apply Monetary Policy Rate (MPR) or Discount Rate to influence the movement of other rates in the country and ultimately the level of inflation, output and employment. These interest rates facilitate the flow of funds from lenders to borrowers. Interest rates further aid the flow of credit in the economy and help financial entities to efficiently carry out financial intermediation roles.

\subsubsection{Return on Equity}

This section presents the trend of return on equity of commercial banks in Nigeria which was measured using net income/shareholders' equity. The trend is depicted in Figure 4.

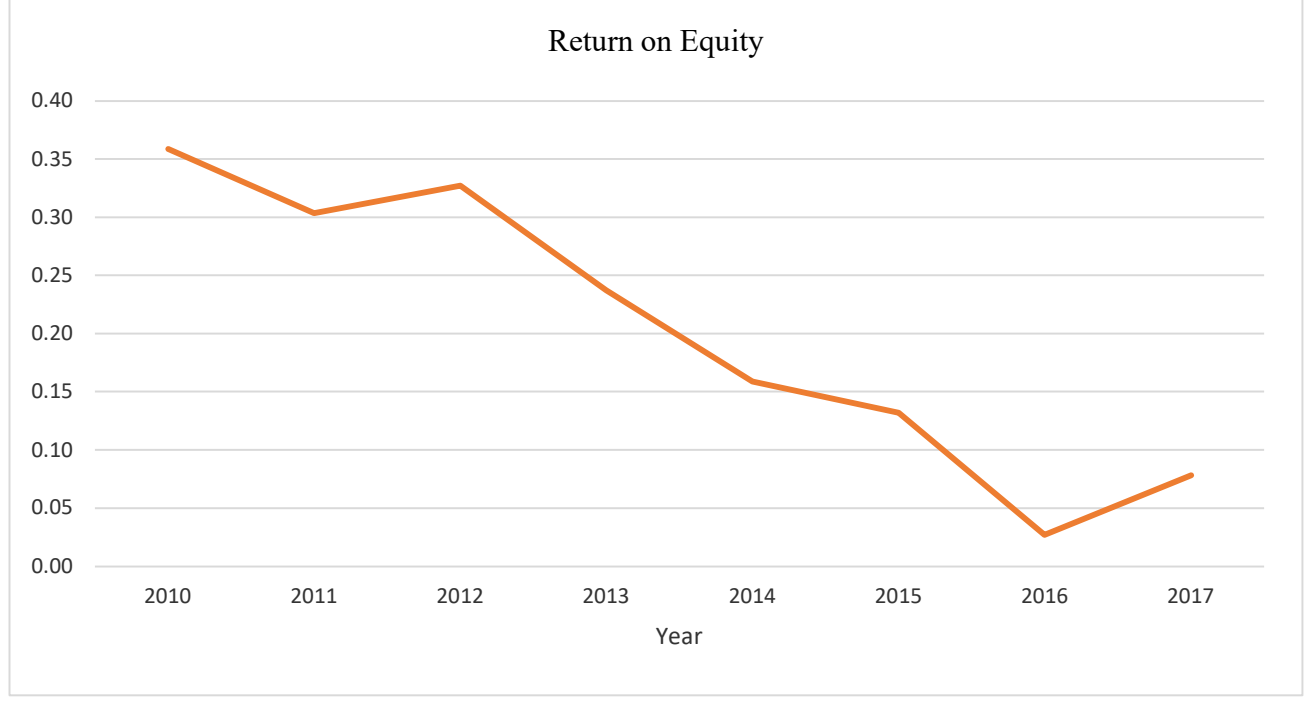

Figure 4: Trend in Return on Equity

Source: Study Data (2019)

The trend depicted in Figure 4 indicates that return on equity of commercial banks in Nigeria had significantly decreased from the year 2010 to the year 2016. However there was a slight increase in the year 2017. The decrease indicated that, most of the banks were not making enough income from invested funds by shareholders. This therefore indicated falling profits and also inefficiency of management in generating returns on shareholders' 
equity.

\subsection{Diagnostic Tests}

The study conducted various pre and post estimation tests. This was to ensure that the assumptions of classical linear regression model (CLRM) were not violated. The tests include: normality test, heteroscedasticity test, autocorrelation test, multicollinearity, stationary test, and test for fixed effect and random effect.

\subsubsection{Normality Test}

Test for normality determines whether the data is well modeled and normally distributed (linear). It is used to measure how far data deviates from the Gaussian by looking at the graph and determining if the distribution deviated grossly from a bell shaped normal distribution. It is a determination of the likelihood of a random variable becoming normally distributed. It is an assessment of the normality of data in statistical tests. To test the normality of the variables, the Jarque-Bera (JB) and normality graph were utilized. The results in Figure 5 indicate that the residuals were normally distributed. In testing for normality, the Jarque-Bera test was preferred as compared to the graphical approach due to its more comprehensive nature (Gujarati, 2003). The results of the test are presented in Figure 5.

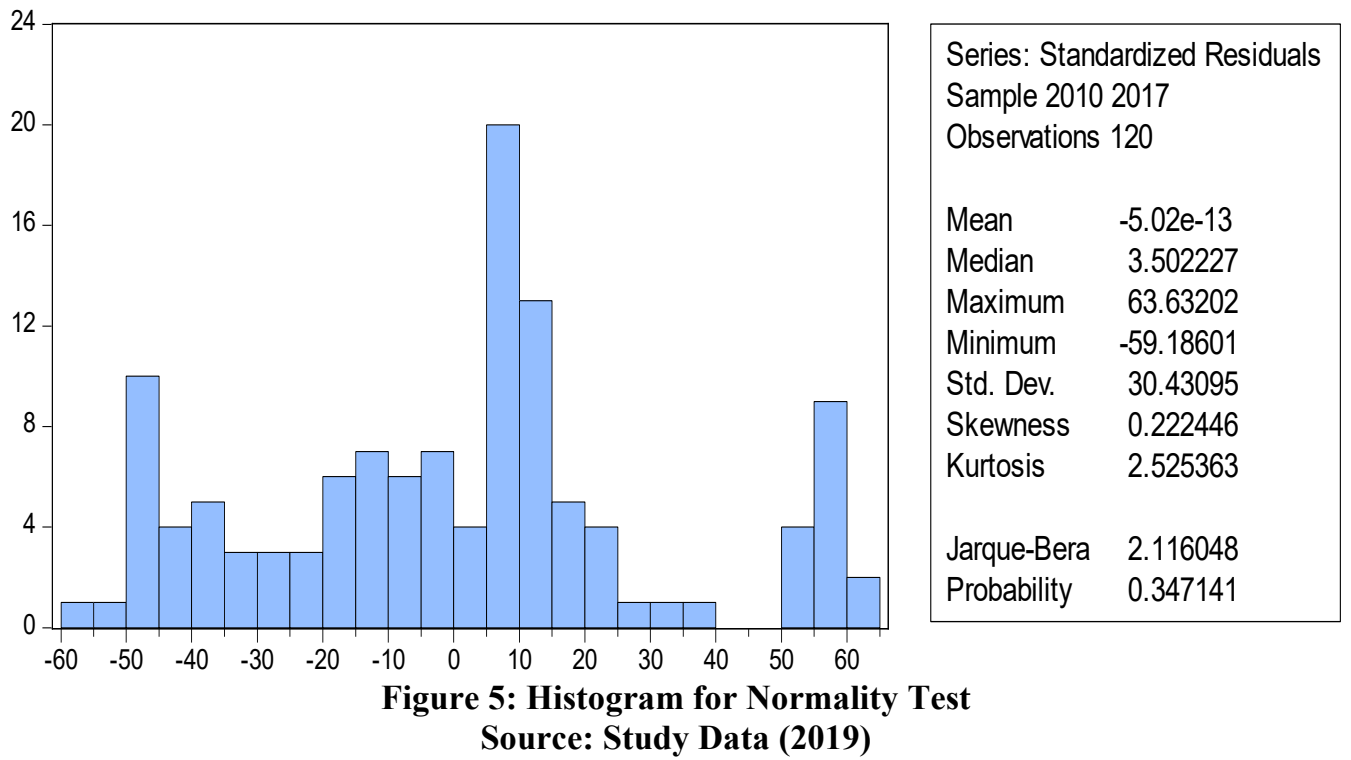

The null hypothesis for this test stated that the data set has a normal distribution. The results in Figure 5 indicate that the $\mathrm{p}$-value for the residual was above 0.05 , therefore, the study failed to reject the null hypothesis and this implied that the data set had a normal distribution. In line with Brooks (2008), the evidence of a normal distribution of the residuals implied that the OLS regression methodology can be utilized for purposes of estimating the panel regression models.

\subsubsection{Heteroscedasticity Test}

Heteroscedasticity test was carried out for the purpose of testing whether the error terms are correlated across observation in the time series data. The error terms from a regression model must have a constant variance called homoscedastic. To ascertain whether the residuals met this criterion, the study applied the Breusch-Pagan test for heteroscedasticity where the null hypothesis stated that the residuals are homoscedastic. A p-value of $>0.05$ implies the existence of constant variance. The results are shown in Table 2.

\section{Table 2: Heteroscedasticity Test Results}

\section{Breusch-Pagan / Cook-Weisberg test for heteroscedasticity}

\section{$\mathrm{H}_{\mathrm{o}}$ : Constant variance}

Variable: fitted values

chi2(15)

Prob $>$ chi2
ROE

1788.63

0.0000

Source: Study Data (2019)

The null hypothesis was therefore rejected at 0.05 significance level since the reported p-value was 0.0000 . The data therefore suffered from heteroscedasticity. This was however corrected with the use of robust standard errors.

\subsubsection{Autocorrelation Test}

The study carried out autocorrelation test for purposes of establishing if the residuals were correlated with respect to time. The study employed the Wooldridge Test for autocorrelation to detect the existence of autocorrelation in the data, that is, whether or not the residual is serially correlated over time. The null hypothesis of this test was 
that there is no first order serial correlation in the data (Brooks, 2008). The results are presented in Table 3.

Table 3: Serial Correlation Tests

Wooldridge test for autocorrelation

$\mathrm{H}_{0}$ : no first-order autocorrelation

$\mathrm{F}(1,14)=40.700$

Prob $>F=0.000$

\section{Source: Study Data (2019)}

The findings in Table 3 indicate that the F statistic had a value of 40.700 and a p-value of 0.000 . The study rejected the null hypothesis and thus concluded that there was a problem of serial correlation covariance. The study corrected the problem of serial correlation covariance using robust standard errors in the regression.

\subsubsection{Multicollinearity Test}

The study tested for multicollinearity by generating the Variance Inflation Factor (VIF) output which was used in ascertaining whether the multicollinearity level was minimal or severe. The VIF of less than 5 for the independent variables is recommendable for eliminating the probability of excessive level of multicollinearity. The findings from the VIF test are presented in Table 4.

Table 4: Multicollinearity Test Results

\begin{tabular}{lll}
\hline Variables & VIF & Remark \\
\hline Price Level Fluctuation & 2.45 & No Multicollinearity \\
Exchange Rate Fluctuation & 1.67 & No Multicollinearity \\
Interest Rate Fluctuation & 2.20 & No Multicollinearity \\
\hline
\end{tabular}

Source: Study Data (2019)

Table 4 indicates that all variables had a VIF value of less than 5 , thereby indicating the absence of severe multicollinearity. As such, the multicollinearity level in the model is minimal and can be tolerated.

\subsubsection{Stationarity Test}

The study conducted a stationarity test on the variables used for purposes of avoiding spurious regressions. Unit root test was conducted using the LLC test to ascertain the stationarity level of the study variables that is, whether they are stationary or non-stationary. The results for stationarity test are presented in Table 5 .

Table 5: Stationarity Test Results

\begin{tabular}{llll}
\hline Variable name & t-Statistic(adjusted) & P-value & Comment \\
\hline ROE & 6.6309 & 0.0015 & Stationary \\
Price Levels & 7.8314 & 0.0006 & Stationary \\
Exchange Rates & 7.7817 & 0.0494 & Stationary \\
Interest Rates & 9.8060 & 0.0000 & Stationary \\
\hline
\end{tabular}

Source: Study Data (2019)

The findings in Table 5 indicate that all the research variables are stationary (that is, absence of unit roots) at 0.05 level of significance.

\subsubsection{Test for Fixed Effect or Random Effect Model}

When performing panel data analysis, there is a need to determine whether to run a random effect model or a fixed effect model. The study used the Hausman's specification test (1978) to choose between fixed and random effect models as presented in Table 6 .

Table 6: Hausman Test for Return on Equity

\begin{tabular}{lllll}
\hline \multicolumn{2}{c}{ ROE } & & \\
\hline & $\mathbf{( b )}$ & $\mathbf{( B )}$ & $\mathbf{( b - B )}$ & Sqrt (diag(V_b-V_B)) \\
& Fixed & Random & Difference & S.E. \\
\hline Price Level Fluctuation & 0.003 & 0.003 & 0.000 & 0.000 \\
Exchange Rate Fluctuation & 0.000 & 0.000 & 0.000 & 0.000 \\
Interest Rate Fluctuation & 0.009 & 0.014 & -0.005 & 0.001 \\
chi2(3) & 7.370 & & & \\
Prob $>$ chi2 & 0.061 & & & \\
\hline
\end{tabular}

\section{Source: Study Data (2019)}

Table 6 presents the results of the hausman test where the null hypothesis stated that the random effect model is the preferred model. Based on the findings from the hausman test, a chi-square of 7.370 and a p-value of 0.061 were established. Therefore, at 0.05 significance level, the value obtained for chi-square is statistically insignificant. The study therefore failed to reject the null hypothesis that random effect model is the preferred model for estimation. Consequently, the random effect model was applied in the study.

\subsection{Correlation Analysis}

Correlation analysis was done to determine the association between the study variables. The correlation analysis 
was based on pearson's correlation method which was obtained using STATA. The correlation analysis was done at 0.05 significance level as indicated by one asterisk $\left(^{*}\right)$. The correlation results are presented in Table 7.

Table 7: Correlation Test Results

\begin{tabular}{lllll}
\hline Variables & ROE & Price Levels & Exchange Rates & Interest Rates \\
\hline ROE & 1.000 & & & \\
Price levels & $0.631^{*}$ & 1.000 & & \\
& 0.000 & & 1.000 & \\
Exchange rates & $-0.589^{*}$ & $-0.613^{*}$ & & \\
& 0.000 & 0.000 & $-0.555^{*}$ & 1.000 \\
Interest Rates & $0.620^{*}$ & $0.724^{*}$ & 0.000 & \\
& 0.000 & 0.000 & &
\end{tabular}

Source: Study Data (2019)

The results in Table 7 indicates that price levels $(\mathrm{r}=0.631, \mathrm{p}=0.000)$ had a positive and significant correlation with return on equity of commercial banks. This is consistent with the studies by Abel and Le Roux (2016) and Yüksel, Mukhtarov, Mammadov and Özsarı (2018) who documented a positive correlation between price levels and return on equity of commercial banks for Zimbabwe and Post-Soviet Countries respectively. Exchange rates $(\mathrm{r}=-0.589, \mathrm{p}=0.000)$ had a negative and significant correlation with return on equity. Interest rates $(\mathrm{p}=0.620$, $\mathrm{r}=0.000$ ) had a positive and significant correlation with return on equity of commercial banks in Nigeria. The findings are in agreement with the study by Khan and Sattar (2014) who found that interest rates had a positive and significant correlation with profitability of commercial banks in Pakistan.

\subsection{Panel Regression Analysis}

This section presents the panel regression analysis which was used in testing the hypotheses of the study. The estimation of the model is reported in Table 8.

Table 8: Regression Results

\begin{tabular}{lllllll}
\hline ROE & Coef. & Std. Err. & T & $\mathbf{P}>|\mathbf{t}|$ & {$[\mathbf{9 5 \%}$ Conf. } & Interval] \\
\hline Price Levels & 0.0027 & 0.0015 & 1.8400 & 0.0660 & -0.0002 & 0.0056 \\
Exchange Rates & -0.0002 & 0.0001 & -1.9100 & 0.0560 & -0.0003 & 0.0000 \\
Interest Rates & 0.0139 & 0.0055 & 2.5500 & 0.0110 & 0.0032 & 0.0246 \\
$\quad$ cons & -0.2185 & 0.0934 & -2.3400 & 0.0190 & -0.4016 & -0.0355 \\
R-sq: Overall $=0.4970$ & & & & & & \\
F statistics $=45.08$ & & & & & & \\
Prob $>$ chi2 $=0.0000$ & & & & & & \\
\hline
\end{tabular}

\section{Source: Study Data (2019)}

The results in Table 8 indicate an R squared of 0.4970 . This implies that price levels, exchange rates and interest rates collectively had high explanatory power on return on equity of commercial banks in Nigeria. The $\mathrm{F}$ statistics value was 45.08 with a p-value of 0.0000 which is less than 0.05 . The findings in Table 8 indicate that price levels had a coefficient of $(\beta=0.0027)$. This is therefore an indication that price levels had a positive effect on return on equity of commercial banks in Nigeria. The positive coefficient implies that a unit increase in price levels amounts to a corresponding increase in the return on equity of commercial banks by 0.0027 . The study findings further indicated that exchange rates had a coefficient of $(\beta=-0.0002)$.

The findings therefore reveal that exchange rates had negative effect on return on equity of commercial banks in Nigeria. This therefore means that a unit increase in exchange rates results in a corresponding 0.0002 decrease in the return on equity of commercial banks in Nigeria. The regression output in Table 8 indicates that interest rates had a coefficient of $(\beta=0.0139)$ which indicates that interest rates had a positive effect on return on equity of commercial banks in Nigeria. This implies that a unit increase in interest rates brings about a corresponding increase in the return on equity of commercial banks in Nigeria by 0.0139 .

\subsection{Hypotheses Testing}

In line with the specific objectives of the study, various null hypotheses were formulated and tested.

$\mathrm{H}_{01}$ : Price Levels have no significant effect on Return on Equity of Commercial Banks in Nigeria

The study sought to examine the effect of price levels on return on equity of commercial banks in Nigeria. The findings of the study are presented in Table 8. To achieve the objective above, a null hypothesis was formulated and tested at 0.05 significance level. The empirical findings $(p=0.066)$ indicates non significance. Therefore, the study failed to reject the null hypothesis that price levels have no significant effect on return on equity of commercial banks in Nigeria. The empirical findings indicate that price levels had an insignificant effect on return on equity of commercial banks in Nigeria.

The result of the study on the effect of price levels on return on equity of commercial banks collaborates those of Kohlscheen et al. (2018), Akinkunmi (2017), Sheefeni (2015), Osamwonyi and Chijuka (2014) and Alper and 
Anbar (2011). These authors also documented that price level fluctuation had an insignificant effect on profitability of commercial banks. Conversely, in variation to this result are the findings by Baba and Nasieku (2016), Antwi and Apau (2015) and Gul et al. (2011). The authors found that price levels had significant effect on profitability of commercial banks. The varying results can be attributed to the different contexts and time periods used in the different studies.

H02: Exchange Rates have no significant effect on Return on Equity of Commercial Banks in Nigeria.

The study sought to assess the effect of exchange rates on return on equity of commercial banks in Nigeria. In view of the specific objective, a null hypothesis which stated that exchange rates has no significant effect on return on equity of commercial banks in Nigeria was tested. Empirical findings in Table $8(p=0.0560)$ indicate non significance. Therefore, the study failed to reject the null hypothesis at 0.05 significance level. Exchange rates therefore are not significant predictors of return on equity of commercial banks in Nigeria.

The findings of the study on the effect of exchange rates on return on equity of commercial banks collaborate those of Almaqtari et al. (2018), Lagat and Nyandema (2016), Majok (2015) and Osuagwu (2014). These authors documented that exchange rates had an insignificant effect on return on equity of commercial banks. Since exchange rate increases imply the devaluation of the local currency, a negative effect of exchange rates on profitability of commercial banks is expected. This is due to the various international banking activities undertaken by banks. This result is however at variance with those of Akani et al. (2016), Baba and Nasieku (2016) and Khrawish (2011) who documented that exchange rates had a significant effect on profitability of commercial banks. These variations can be attributed to the contexts and methodological approaches of the studies.

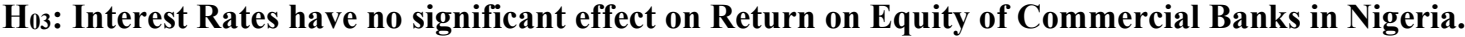

Another objective of the study was to establish the effect of interest rates on return on equity of commercial banks in Nigeria. The findings on this objective are presented in Table 8. In view of this objective, the null hypothesis above was formulated and tested at 0.05 significance level. The research findings $(p=0.011)$ indicate that interest rates had a significant effect on return on equity of commercial banks in Nigeria. The corresponding null hypothesis was therefore rejected at 0.05 significance level. Commercial banks' activities are centered on financial intermediation, as such the amount of interest paid by borrowers on loans which is the lending rate of banks determines the level of bank profitability. Increases in lending rates account for increases in profitability of commercial banks.

The empirical findings of the study with respect to the effect of interest rates on return on equity are in agreement with the results by Ahmed (2018) who reported that interest rates had a significant effect on return on equity of commercial banks in Pakistan. Additionally, Akani et al. (2016), Baba and Nasieku (2016) and Osamwonyi and Chijuka (2014) also documented that interest rates had a significant effect on return on equity of commercial banks in Nigeria. This therefore implies that interest rates are key predictors of return on equity of commercial banks. The findings of the study are also in line with those of Kanwal and Nadeem (2013) and Alper and Anbar (2011) who found that interest rates had a significant effect on return on equity of commercial banks in Pakistan and Turkey respectively. Contrary to this result is the study by Lagat and Nyandema (2016) who reported that interest rates had an insignificant effect on return on equity of commercial banks in Nigeria. The different contexts which the studies were carried out can be the possible reason for the variations in results.

\subsection{Conclusion and Recommendations}

The study concluded that that price levels does not significantly predict the return on equity of commercial banks in Nigeria. Therefore increasing price levels are not key in affecting the return on equity of commercial banks in Nigeria. The effect on exchange rates on return on equity was found to be insignificant. The study therefore concluded that exchange rates had insignificant effect on return on equity of commercial banks in Nigeria.

The effect of interest rates on return on equity of commercial banks in Nigeria was found to be significant. The study therefore recommends that price discrimination can come into play so as to apply different interest rates on loans to different customers which can be guided by their credit history. Additionally, the Central Bank should put in place effective monitoring mechanism in line with floors and ceiling for lending rates so as to protect customers from exploitation by commercial banks.

\subsection{Suggestions for Further Research}

The suggestions for further research are based on the unique findings of the study. The study documented that price levels had an insignificant effect on return on equity of commercial banks which is however contrary to expectations. Price levels are expected to significantly predict the profitability levels of commercial banks. The direction of this effect is however dependent on whether price levels were fully anticipated or not. In view of this result, the study recommends that further studies can be done on the effect of price levels on return on equity of commercial banks in Nigeria. This can be based on a wider time period and different methodology.

The study further reported that exchange rates had insignificant effect on return on equity of commercial banks in Nigeria. This is contrary to expectations as commercial banks in Nigeria carry out international banking 
activities across countries and currencies. Additionally, most of the banks have operational offices and branches outside Nigeria. These, therefore, make the banks susceptible to the variations in exchange rates. Empirical research can be done to further examine the linkages between exchange rates and return on equity of commercial banks in Nigeria. Further studies can be done based on wider time scope and sample size.

\section{References}

Abel, S. \& Le Roux, P. (2016). Determinants of Banking Sector Profitability in Zimbabwe. International Journal of Economics and Financial Issues, 6 (3), 845-854.

Akims, M. A (2016). Effect of Macroeconomic Factors on External Reserves in Nigeria. M.Sc Thesis, Kenyatta University, Kenya.

Akinkunmi, M. (2017). Determinants of Banks' Profitability in Nigeria: Does Relative Market Power Matter? Journal of Finance and Bank Management, 5 (1), 42-53.

Al-Khouri, R (2012). Bank Characteristics and Liquidity Transformation: The Case of GCC Banks. International Journal of Economics and Finance, 4 (12), 114-120.

Alper, D. \& Anbar, A. 2011. 'Bank Specific and Macroeconomic Determinants of Commercial Bank. Profitability: Empirical Evidence from Turkey', Business and Economics Research Journal, 2 (2), 139-152.

Almaqtari, F. A., Al-Homaidi, E. A., Tabash, M. I \& Farhan, N. J (2018). The Determinants Of Profitability Of Indian Commercial Banks: A Panel Data Approach. International Journal of Finance and Economics, 24 168-185.

Antwi, F. \& Apau, E. V. 2015. 'Financial Performance of Rural and Community Banks (RCBs) in Ghana', The International Journal Of Business \& Management, 3 (2), 76-85.

Aremu, M. A., Ekpo, I. C. \& Mustapha, A. M. (2013). Determinants of Banks' Profitability in a Developing Economy: Evidence from Nigerian Banking Industry. Interdisciplinary Journal of Contemporary Research in Business, 4 (9), 155-181.

Babazadeh, M., \& Farrokhnejad, F. (2012). Effects of Short-run and Long-run Changes in Foreign Exchange Rates on Banks' Profit. International Journal of Business and Management, 7 (17), 70-77.

Baba, S \& Nasieku, T (2016) Effect of Macroeconomic Factors on Financial Performance Of Commercial Banks In Nigeria. International Journal of Social Sciences and Information Technology, 2 (9), 1278-1299.

Bektas, E. (2014). Are the determinants of bank net interest margin and spread different? The case of North Cyprus. Banks and Bank Systems, 9(4), 82-91.

Bilal, M., Saeed, A., Gull, A., A \& Akram, T. (2013). Influence of Bank Specific and Macroeconomic Factors on Profitability of Commercial Banks: A Case Study of Pakistan. Research Journal of Finance and Accounting, 4 (2), 117- 126.

Brooks, C. (2008). Introductory Econometrics for Finance. Cambridge University Press. Cambridge: 161.

Central Bank of Nigeria (2016). Financial Stability Report; Reuters - Fitch: Nigeria Bank Street Test Highlights Disparity in Capital.

Cooper, D. \& Schindler, P. (2009). Business Research Methods (9thed.). Boston: McGraw- Hill.

Estes, B. \& Polnick, B. (2012), Examining motivation theory in higher education: An expectancy theory analysis of tenured faculty productivity. Journal of Management, Business and Administration, 15(1), 1-7.

Flamini, V., McDonald, C. A., \& Schumacher, L. B. (2009). The determinants of commercial bank profitability in Sub-Saharan Africa. IMF Working Papers (9), 1-30.

Gul, S., Irshad, F., \& Zaman, K. (2011). Factors Affecting bank Profitability in Pakistan. The Romanian Economic Journal, 14 (39), 60-87.

Gujarati,D.(2003) .Basic Econometrics. 4th ed. McGraw Hill pg. 638-640, New York.

Kanwal, S., \& Nadeem, M. (2013). The impact of macroeconomic variables on the profitability of listed commercial banks in Pakistan. European Journal of Business and Social Sciences, 2 (9), 186-201.

Khan, W. A. \& Sattar, A. (2014). Impact of Interest Rate Changes on the Profitability of four Major Commercial Banks in Pakistan. International Journal of Accounting and Financial Reporting, 4 (1), 142-154.

Khrawish, H. A. (2011). Determinants of commercial banks performance: evidence from Jordan. International Research Journal of Finance and Economics, 5 (5), 19-45.

Kimani, G. M \& Koori, J (2018). Monetary Policy And Financial Performance Of Commercial Banks In Kenya. International Journal of Management and Commerce Innovations 6 (1), 1893-1903.

Kohlscheen, E., Murcia, A \& Contreras, J. (2018). Determinants of bank profitability in emerging markets. BIS Working Papers No 686 Monetary and Economic Department. Bank for International Settlement. Page 1-24

Lagat, C., C \& Nyandema, D., M (2016). The Influence Of Foreign Exchange Rate Fluctuations On The Financial Performance Of Commercial Banks Listed At The Nairobi Securities Exchange. British Journal of Marketing Studies, 4 (3), 1-11

Majok, E. (2015). Effects of Exchange Rate Fluctuations on Financial Performance of Commercial Banks in Kenya. Unpublished MBA Project, University of Nairobi, Kenya. 
Muraina, S. A (2018). Determinants of Listed Deposit Money Banks' Profitability in Nigeria International Journal of Finance and Banking Research, 4 (3), 40-56.

Osamwonyi, I. O \& Chijuka, I. M (2014) The Impact of Macroeconomic Variables on the Profitability of Listed Commercial Banks in Nigeria. European Journal of Accounting Auditing and Finance Research, 2 (10), 8595.

Osuagwu, E. S. (2014). Determinants of bank profitability in Nigeria, International Journal of Economics and Finance, 6(12), 46-63.

Osundina, C., Ademola, O., Jayeoba, O \& Olayinka, I (2016). Exchange Rate Volatility and Banks Performance: Evidence from Nigeria. International Journal of Economics and Business Management. 2 (4), 1-11.

Ramli, M. S., \& Jusoh, A. B. (2015). Expectancy Theory Analysis to Conduct Research at Malaysian Research University. International Journal of Economics and Financial Issues, 5(Special Issue) 366-372.

Rashid, A. (2013). CEO duality and agency cost: Evidence from Bangladesh. Journal of Management and Governance, 17 (4), 989-1008.

Sheefeni, J. P (2015). The Macroeconomic Determinants of Profitability among Commercial Banks in Namibia. Journal of Emerging Issues in Economics, Finance and Banking (JEIEFB) An Online International Research Journal. 4 (1), 1414-1431.

Tariq, W., Usman, M., Mir, H.Z., Aman, I. \& Ali, I. (2014). Determinants of Commercial Banks Profitability: Empirical Evidence from Pakistan. International Journal of Accounting and Financial Reporting, 4(2), 21623082.

Williams, H. T (2018). An Empirical Investigation of The Impact Of Exchange Rate Fluctuations On The Performance of Selected Listed Firms In Nigeria. Journal of Business Management and Economic Research $2(3), 1-10$.

World Bank (2020), Bank's Return on Equity for Nigeria [DDEI06NGA156NWDB], retrieved from FRED, Federal Reserve Bank of St. Louis; https://fred.stlouisfed.org/series/DDEI06NGA156NWDB, February 14, 2020.

Yüksel, S., Mukhtarov. S., Mammadov. E. \& Özsarı, M. (2018). Determinants of Profitability in the Banking Sector: An Analysis of Post-Soviet Countries. Economies. 6. 41. 10.3390/economies6030041. 